\title{
(2) OPEN ACCESS \\ Malignant ascites following radical nephrectomy for cystic renal cell carcinoma
}

\author{
Nicolas Adrianto Soputro, ${ }_{1}^{1,2}$ Jada Kapoor, ${ }_{1}^{2}$ Homayoun Zargar, ${ }_{1}^{2}$ \\ Brendan Hermenigildo Dias ${ }^{2}$
}

'Department of Surgery, Western Health, Footscray, Victoria, Australia

${ }^{2}$ Urology, Western Health, Footscray, Victoria, Australia

\section{Correspondence to}

Dr Nicolas Adrianto Soputro; nicolas.soputro@wh.org.au

Accepted 27 June 2021
Check for updates

(C) BMJ Publishing Group Limited 2021. Re-use permitted under CC BY-NC. No commercial re-use. See rights and permissions. Published by BMJ.

To cite: Soputro NA, Kapoor J, Zargar H, et al. BMJ Case Rep 2021;14:e243103. doi:10.1136/bcr-2021-

243103

\begin{abstract}
SUMMARY
A 69-year-old man with a history of laparoscopic radical nephrectomy for papillary renal cell carcinoma presented with a 1-week history of generalised abdominal pain, distension and loss of appetite. Clinical examination and CT imaging demonstrated ascites associated with peritoneal nodules, raising the possibility of metastatic disease. Immunochemistry staining from ascites fluid cytology confirmed renal cell carcinoma. Following multidisciplinary discussions, the patient was commenced on a small-molecule tyrosine kinase inhibitor.
\end{abstract}

\section{BACKGROUND}

Cystic forms of renal cell carcinoma (cRCC) are the leading cause of malignant cystic renal lesion and may represent up to $14 \%$ of RCC lesions. They are known for their good prognostic factors as they typically present with smaller lesions, are of lower nuclear grade and have lower risk of recurrence and metastasis. Peritoneal carcinomatosis and malignant ascites are uncommon in RCC. They might be attributed to direct tumour extension or metastasis via haematogenous spread or tumour seeding from prior surgical resection. ${ }^{1-3}$

We report a case of symptomatic malignant ascites with evident peritoneal nodules diagnosed 5 months following a laparoscopic radical nephrectomy for a Bosniak IV malignant cystic renal mass, later identified as pT2, Fuhrman grade 2, type 1 papillary RCC (pRCC).

\section{CASE PRESENTATION}

A 69-year-old man presented to the emergency department with a 1-week history of worsening generalised abdominal pain, abdominal distension and loss of appetite. His clinical examination indicated the presence of ascites associated with generalised mild abdominal tenderness. $\mathrm{He}$ was haemodynamically stable with no evidence of systemic infection. There were no features suggestive of peritonism.

This presentation occurred 5 months following a laparoscopic left radical nephrectomy for an $80 \mathrm{~mm}$ contrast-enhancing, Bosniak IV left lower pole cystic renal mass. The procedure was performed via a transperitoneal approach, with care taken to avoid spillage by first aspirating the cystic content, which was sent for cytological analysis. Gauze was then used over the ruptured portion of the cyst to further minimise spillage during dissection until the specimen was bagged and delivered through a separate left abdominal incision. The renal bed was then irrigated with distilled water. The patient had an uneventful recovery and was discharged the following day.

Histopathology of the specimen showed a pT2 $\mathrm{Nx}$ type $1 \mathrm{pRCC}$, nuclear grade 2 , with the greatest tumour dimension of $80 \mathrm{~mm}$ (figure 1). Necrotic features were evident. Negative surgical margin was achieved, and all tumours were shown to be confined within the renal capsule without lymphovascular invasion. There was no evidence of rhabdoid or sarcomatoid differentiation. The cytology from the aspirated cystic content showed no evidence of malignancy.

He had no other surgical or malignancy history. His other comorbidities included hypertension, gastro-oesophageal reflux disease, scoliosis and previous occupational asbestos exposure. He was a non-smoker and non-alcohol drinker.

\section{INVESTIGATIONS}

CT of the chest, abdomen and pelvis identified a moderate-volume ascites with evidence of peritoneal nodules. Other findings included right pleural effusion and a $14 \mathrm{~mm}$ right apical subpleural nodule (figure 2). There was no locoregional recurrence in the left renal bed.

Diagnostic paracentesis was performed with the resulting fluid biochemistry as follows: lactate dehydrogenase of $1255 \mathrm{U} / \mathrm{L}$, total protein of $53 \mathrm{~g} / \mathrm{L}$, $\mathrm{pH} 7.76$ and alkaline phosphatase of $51 \mathrm{U} / \mathrm{L}$. Fluid cytology showed neoplastic cells with moderate amount of eosinophilic cytoplasm and rare papillary-like structures. Immunochemistry staining showed PAX8-positive, CD10-positive and CK7positive cells consistent with carcinoma of renal origin (figure 3). There was no bacterial growth from the ascitic fluid culture.

\section{OUTCOME AND FOLLOW-UP}

$\mathrm{He}$ demonstrated good clinical improvement following the ascitic tap on presentation. Repeat ultrasound (US) prior to discharge from inpatient services showed marked interval reduction of the ascites volume.

$\mathrm{He}$ was subsequently reviewed by the Medical Oncology team, which commenced on $20 \mathrm{mg}$ daily dose of cabozantinib, a small-molecule tyrosine kinase inhibitor. He initially reported good improvement in his abdominal pain symptoms within 1 month of therapy commencement. This improvement was further supported by a repeat staging CT of the brain, chest, abdomen and pelvis, showing stable peritoneal and pulmonary nodules 

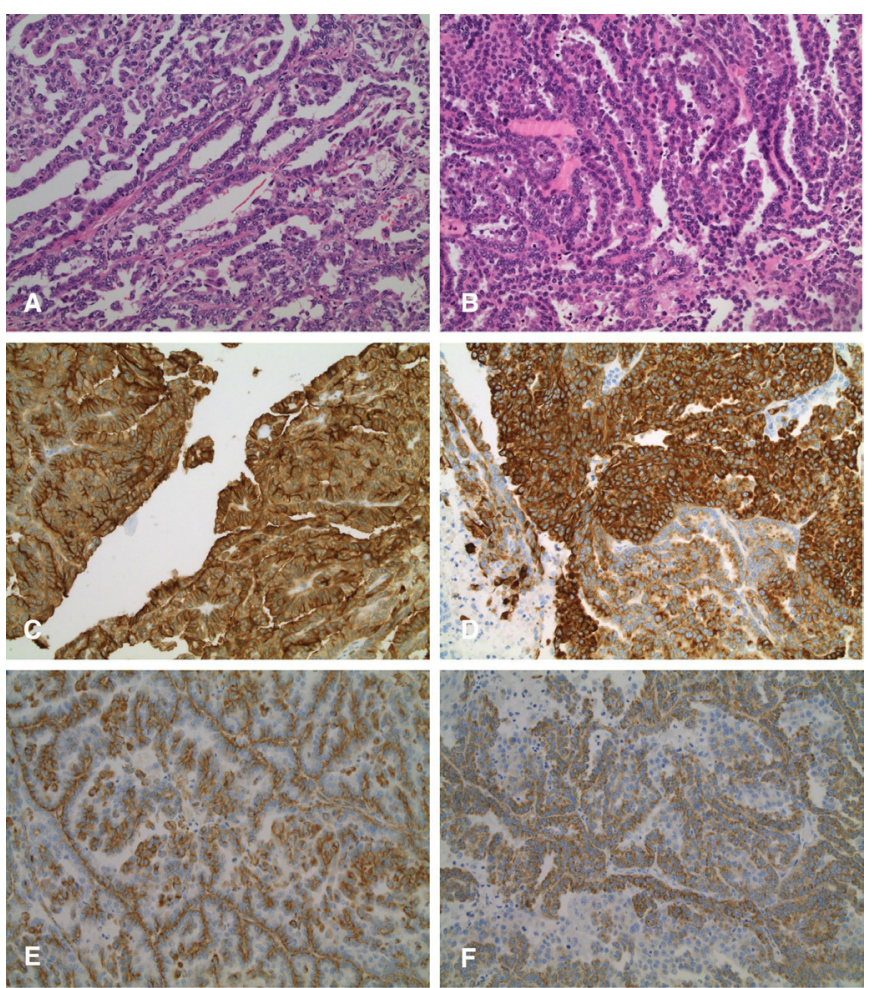

Figure 1 ( $A-B)$ Histopathology sections with H\&E stain showing invasive carcinoma of predominantly papillary architecture $(\times 200)$. (C) CD10-positive cells ( $\times 200)$. (D) CK7-positive cells $(\times 200)$. (E) Vimentinpositive cells $(\times 200)$. (F) AMACR-positive cells $(\times 200)$.

and resolution of ascites and pleural effusion. There was no evidence of other metastatic foci on CT and whole-body bone scan.

Shortly following a trial of higher dosage, the patient developed multiple symptoms, including chest pain, abdominal pain, heartburn and swelling on his hands and feet, prompting subsequent decision for dose reduction. He subsequently developed recurrence of malignant ascites, occurring 5 months after his presentation to the emergency department, which was managed with regular paracentesis due to reaccumulation.

\section{DISCUSSION}

RCCs are the most frequently encountered primary malignancy of the kidney. They refer to a group of cancers originating from
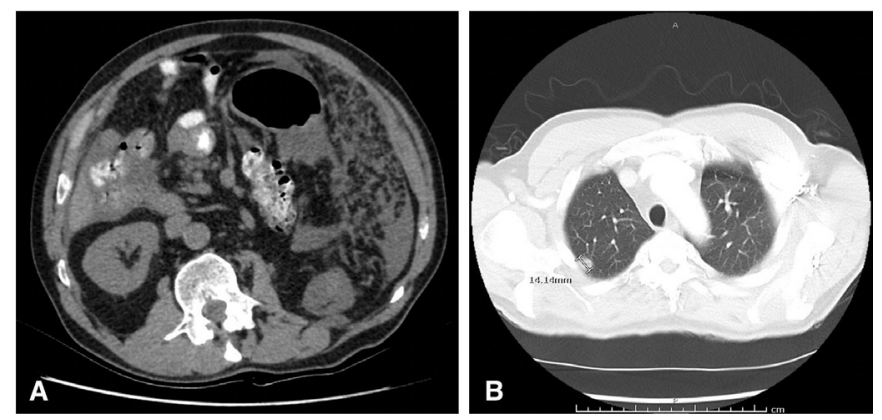

Figure 2 (A) CT image slice demonstrating peritoneal nodules and moderate-volume ascites, as well as previous evidence of left nephrectomy without any visible recurrence on the left renal bed. (B) CT image slice showing an ovoid $14 \mathrm{~mm}$ subpleural nodule within the apical segment of right upper lobe.
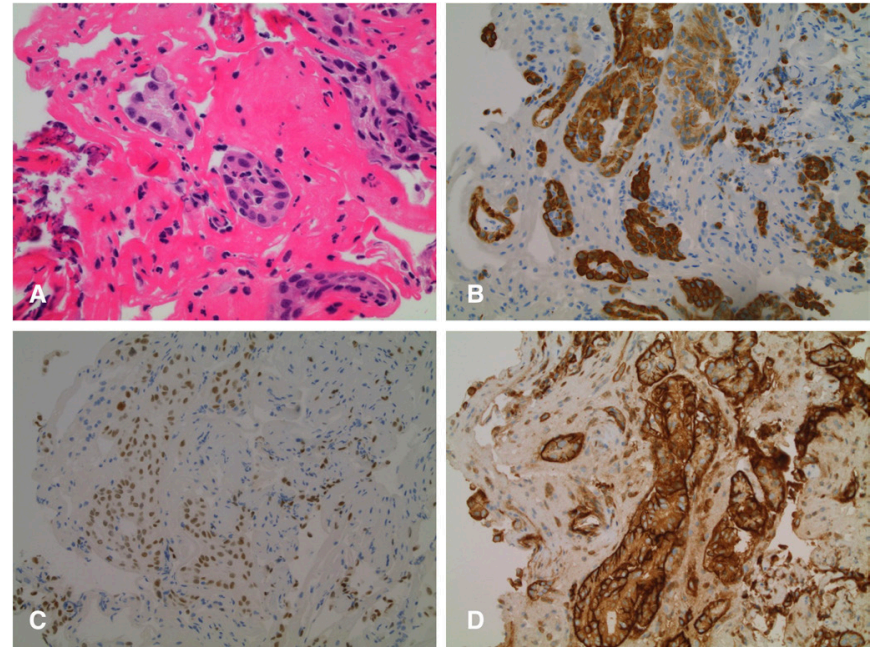

Figure 3 (A) H\&E stain on cytology slides obtained from ascitic fluid showing atypical polygonal cells with rare papillary-like structures and neoplastic cells with moderate amounts of eosinophilic cytoplasm, as well as enlarged and elongated nucleoli ( $\times 200)$. (B) CK7-positive cells (×200). (C) PAX8-positive cells (×200). (D) CD10-positive cells ( $\times 200)$.

the renal epithelial cells, which may arise either sporadically or as a familial disease. They can be categorised into different histological subtypes, with clear cell RCC (ccRCC) as the most common, followed by pRCC, chromophobe, oncocytoma, collecting duct and not otherwise specified (NOS). ${ }^{4}$ Most RCC cases are diagnosed incidentally as either solid or cystic mass through radiological imaging modalities, such as US, CT or MRI. ${ }^{5}$ Despite mostly present in the form of solid mass, approximately 1\%-14\% may have cystic components. More commonly known as cRCC, they are the leading cause of malignant cystic lesions in the kidney. ${ }^{5-7}$ They can manifest as intrinsic unilocular cysts, intrinsic multilocular cysts, cysts with necrotic features and unilocular cysts originating from existing mural tumours. ${ }^{67}$ Most of the different RCC histological subtypes can present as these complex cysts. but among which ccRCCs and pRCCs are the two most common. ${ }^{8-10}$

cRCCs are known to confer good prognosis, especially following surgical resection, as they typically present with smaller tumour size and of lower stage and grade. ${ }^{8-11}$ Winters et al demonstrated these through a retrospective study comparing 678 cRCCs with 46677 solid ccRCCs, where cRCCs were reported to be significantly smaller (mean size of $38 \mathrm{~mm}$ for cRCC vs $45 \mathrm{~mm}$ for solid ccRCC, $\mathrm{p}<0.001$ ), of lower stage (pT1a 66\% for cRCC vs 55\% for solid ccRCC, p<0.001) and more commonly well differentiated (33\% for cRCC vs $16 \%$ for solid ccRCC, $\mathrm{p}<0.001)$. Winters et al also highlighted those with cystic necrosis, such as demonstrated in our patient, to have lower 4-year survival of $80 \%$ compared with $100 \%$ without necrotic features. ${ }^{11}$

The characterisation of cystic renal lesion relies on the Bosniak Classification, which provided means to stratify malignancy risks based on a multitude of radiological features, including the appearance of cyst wall, cystic content, septation, calcifications and contrast enhancement. ${ }^{8}$ Bosniak IIF, III and IV lesions are more likely to be cancerous, each with malignancy risks of 5\%-38\%, 40\%-70\% and 90\%-91\%, respectively. ${ }^{8-10}$ The latter two were more often referred for surgical management as, in addition to the risk of being malignant, higher Bosniak categories were known to be associated with raised likelihood of pT3-4 tumours (IIF 0\% vs III 3.5\% vs IV $15.6 \%, \mathrm{p}=0.04$ ) and 
of the higher nuclear grade $3-4$ tumours (IIF $0 \%$ vs III $12 \%$ vs IV $36 \%, \mathrm{p}<0.001$ ), as demonstrated by Nouhaud et al and Boissier et al, respectively. ${ }^{8}{ }^{9}$ Bosniak categories, however, were not associated with increased incidence of recurrence or differences in the 5 -year recurrence-free survival (IIF $82 \%$ vs III $92 \%$ vs IV $92 \%, \mathrm{p}=0.60){ }^{8-10}$

The recurrence rate of malignant cystic renal lesions following surgical resection, including those presenting as locoregional recurrence or distant metastases, is relatively low, ranging between $1.1 \%$ and $8.6 \% .^{8-10}$ More common metastatic sites include retroperitoneal lymph nodes, lung, liver, bone and brain. Peritoneal involvement in RCC, which can lead to malignant ascites, as observed in our case was relatively uncommon, only affecting $1 \%$ of the population. ${ }^{2}$ Nevertheless, the incidence of malignant ascites appeared to be higher in pRCC, compared with other histological subtypes of RCC, even in the absence of other distant metastatic sites. These were demonstrated by Sidana $e t$ al, who found malignant ascites in $20 \%$ of their 100 patients with pRCC. Of the 20 patients with ascites, distant metastatic sites at the time of diagnosis were identified in $30 \%$ with no significant differences compared with $24.1 \%$ patients without ascites $(p=0.609)$. More importantly, malignant ascites was recognised as a poor prognostic indicator with significantly reduced median overall survival in those affected $(25$ months in patients with ascites vs 42.5 months in patients without ascites, $\mathrm{p}=0.041){ }^{1}$

The relatively high prevalence of malignant ascites reported by Sidana $e t$ al may be surprising given the limited number of prior publications for evidence of peritoneal carcinomatosis and/or malignant ascites attributed to RCC. Based on previous reports, peritoneal carcinomatosis, with or without ascites, can be associated with ccRCC, pRCC and NOS histological subtypes. ${ }^{2}{ }^{2-18}$ As reported by Sidana $e t a l$, ascites may develop up to 73 months following the initial RCC diagnosis with a median time of 16 months. ${ }^{1}$ As reflected in table 1 , peritoneal carcinomatosis may also be identified before or after primary tumour resection. ${ }^{212-18}$ Ploumidis et al identified a $5 \mathrm{~mm}$ omental nodule 24 months after a transperitoneal robot-assisted radical nephrectomy for a Fuhrman grade 1, pT2 pRCC. ${ }^{12}$ Pandey et al reported a case of multiple peritoneal nodules at the ileocolic junction diagnosed on exploratory laparotomy for right iliac fossa pain 6 months after radical nephrectomy. ${ }^{13}$ Similar to our patient, the two postoperative peritoneal carcinomatosis cases were diagnosed together with other potential distant metastatic foci, with ours being the subpleural apical nodule. ${ }^{12} 13$

In terms of pathophysiology, it was postulated that peritoneal carcinomatosis in RCC might be secondary to either direct tumour extension outside of the renal capsule and Gerota's fascia, or an embolic haematogenous metastatic event into the omentum, mesentery and peritoneum. ${ }^{12}{ }^{14}$ However, considering the possibility of the disease to manifest in the setting of smaller, low-stage and low-grade primary tumours, such as the Fuhrman grade 2, pT2 pRCC lesion in our case and the grade 1, pT2a pRCC lesion reported by Ploumidis et al, ${ }^{12}$ the latter hypothesis might be more likely. Certain general factors can contribute to tumour recurrence, which can be differentiated into tumour-related factors, local wound and patient's immune response, as well as surgical approach and perioperative complications. ${ }^{19}$ Through their multivariate analysis, Boissier et al identified Fuhrman grade 4 tumours and patient's general status at the time of surgery in the form of their American Society of Anaesthesiologist (ASA) score to be prognostic factors for recurrence. $^{8}$

Regarding surgical approach, the cystic nature of cRCC should necessitate caution to minimise the risk of perioperative cyst rupture, which may lead to consequent seeding. This is more relevant for cRCC, for the smaller, well-localised and well-differentiated tumours often prompt clinicians to consider less invasive approaches, in the likes of laparoscopic and/or nephron-sparing surgeries. Chen et al identified that factors such as greater endophytic properties of the tumour, closer proximity to renal collecting system, Bosniak III lesions and surgeon's experience correlate with risk of intraoperative cyst rupture. ${ }^{3}$ However, despite the risk, the incidence of tumour seeding following urological laparoscopic surgery is relatively low, ranging between $0.1 \%$ and $4 \%,{ }^{19}$ and the cyst rupture may not necessarily cause tumour seeding and subsequent recurrence. In a study involving 268 partial nephrectomy patients with $18.7 \%$ incidence of cyst rupture, Pradere et al found no evidence of recurrence or peritoneal carcinomatosis and port-site metastasis

Table 1 Previously published case reports of peritoneal carcinomatosis secondary to different histological subtypes of RCC, with or without malignant ascites

\begin{tabular}{|c|c|c|c|c|c|c|c|c|c|c|}
\hline Author (year) & Age & Gender & $\begin{array}{l}\text { RCC } \\
\text { subtype }\end{array}$ & Laterality & $\begin{array}{l}\text { Prior surgery } \\
\text { (primary surgery type and method, } \\
\text { months following primary surgery) }\end{array}$ & $\begin{array}{l}\text { pT } \\
\text { stage }\end{array}$ & Grade & $\begin{array}{l}\text { Peritoneal } \\
\text { carcinomatosis }\end{array}$ & Ascites & $\begin{array}{l}\text { Other metastatic } \\
\text { foci }\end{array}$ \\
\hline $\begin{array}{l}\text { Pandey et al. } \\
(2018)^{13}\end{array}$ & 22 & $\mathrm{~F}$ & cCRCC & $\mathrm{R}$ & Yes (radical nephrectomy, 6 months) & $\mathrm{T} 2$ & 4 & Yes & Yes & Left ovarian— radical \\
\hline $\begin{array}{l}\text { Jennison et al. } \\
(2015)^{14}\end{array}$ & 67 & M & $\mathrm{CCRCC}$ & $\mathrm{R}$ & No & - & - & Yes & Yes & - \\
\hline $\begin{array}{l}\text { Staderini et al. } \\
(2015)^{15}\end{array}$ & 70 & M & cCRCC & L & No & T4 & - & Yes & No & Bilateral lungs \\
\hline $\begin{array}{l}\text { Gonçalves et al. } \\
(2014)^{16}\end{array}$ & 58 & M & $\mathrm{CCRCC}$ & L & No & - & - & Yes & Yes & - \\
\hline $\begin{array}{l}\text { Esnakula et al. } \\
(2013)^{17}\end{array}$ & 53 & $M$ & NOS & L & No & - & High & Yes & Yes & $\begin{array}{l}\text { Liver } \\
\text { Bilateral lungs } \\
\text { Hilar lymph nodes }\end{array}$ \\
\hline $\begin{array}{l}\text { Boateng et al. } \\
(2013)^{18}\end{array}$ & 66 & M & NOS & $\mathrm{R}$ & No & - & - & Yes & Yes & - \\
\hline $\begin{array}{l}\text { Ploumidis et al. } \\
(2013)^{12}\end{array}$ & 75 & M & $\mathrm{pRCC}$ & $\mathrm{R}$ & $\begin{array}{l}\text { Yes (robot-assisted radical nephrectomy, } \\
24 \text { months) }\end{array}$ & $\mathrm{T} 2 \mathrm{a}$ & 1 & Yes & No & Cervix \\
\hline $\begin{array}{l}\text { Stavropoulos et al. } \\
(1995)^{2}\end{array}$ & 70 & $M$ & $\mathrm{cCRCC}$ & L & No & T4 & 3 & Yes & No & - \\
\hline
\end{tabular}

Gender: $\mathrm{F}=$ female, $\mathrm{M}=$ male; RCC subtypes: $c$ RCC=clear cell renal cell carcinoma, NOS=not otherwise specified, pRCC=papillary renal cell carcinoma; laterality: R=right, $\mathrm{L}=$ left; $(-)=$ not reported. RCC, renal cell carcinoma. 
up to 100 months postoperatively. ${ }^{20}$ A prior study by Spaliviero et al involving 284 laparoscopic partial nephrectomy cases echoed a similar phenomenon, whereby only one retroperitoneal recurrence was reported 14 months postoperatively despite the negative margins and absence of intraoperative cyst rupture in all cases. ${ }^{21}$ The study by Chen et al also highlighted that only four of nine patients with recurrence were reported to have cyst rupture, and no association can be derived between cyst rupture with the site of recurrence $(p=1.00) .{ }^{3}$ Our case was an example of recurrence presenting as peritoneal carcinomatosis following a laparoscopic radical nephrectomy in the setting of negative cytology from the aspirated cystic content intraoperatively without any involvement of the renal bed or retroperitoneal lymph node. One potential explanation can be that tumour recurrence is more associated with the aggressiveness of the primary malignancy rather than intraoperative cyst rupture, as the malignant component of cystic tumours is usually more limited to its solid portion. ${ }^{20}$

\section{Learning points}

- Peritoneal carcinomatosis and malignant ascites, although being uncommon in renal cell carcinoma (RCC), are important to recognise as it may indicate poor prognosis.

- Recurrence of cystic RCC may occur following surgical resections, even in those of lower stage and lower nuclear grade primary tumours.

- High incidence of intraoperative cyst rupture in malignant cystic renal lesions does not always translate to tumour seeding, but appropriate perioperative planning and intraoperative measures still need to be applied to minimise the risks.

Acknowledgements The authors thank Dr Benjamin Popp, Anatomical Pathologist, Dorevitch Pathology Footscray Hospital.

Contributors NAS was involved in data curation, writing the original draft, and review and editing JK, HZ and BHD were involved in conceptualisation and review and editing.

Funding The authors have not declared a specific grant for this research from any funding agency in the public, commercial or not-for-profit sectors.

Competing interests None declared.

Patient consent for publication Obtained.

Provenance and peer review Not commissioned; externally peer reviewed.

Open access This is an open access article distributed in accordance with the Creative Commons Attribution Non Commercial (CC BY-NC 4.0) license, which permits others to distribute, remix, adapt, build upon this work non-commercially, and license their derivative works on different terms, provided the original work is properly cited and the use is non-commercial. See: http://creativecommons.org/ licenses/by-nc/4.0/.

\section{REFERENCES}

1 Sidana A, Kadakia M, Friend JC, et al. Determinants and prognostic implications of malignant ascites in metastatic papillary renal cancer. Urol Oncol 2017;35:114. e9-114.e14.

2 Stavropoulos NJ, Deliveliotis C, Kouroupakis D, et al. Renal cell carcinoma presenting as a large abdominal mass with an extensive peritoneal metastasis. Urol Int 1995;54:169-70.

3 Chen S-Z, Wu Y-P, Chen S-H, et al. Risk factors for intraoperative cyst rupture in partial nephrectomy for cystic renal masses. Asian J Surg 2021;44:80-6.

4 Cohen HT, McGovern FJ. Renal-Cell carcinoma. N Engl J Med 2005:353:2477-90.

5 Chen $\mathrm{S}$, Jin B, Xu L, et al. Cystic renal cell carcinoma: a report of 67 cases including 4 cases with concurrent renal cell carcinoma. BMC Urol 2014;14:1-6.

6 Jhaveri K, Gupta P, Elmi A, et al. Cystic renal cell carcinomas: do they grow, metastasize, or recur? AJR Am J Roentgenol 2013;201:W292-6.

7 Han K-R, Janzen NK, McWhorter VC, et al. Cystic renal cell carcinoma: biology and clinical behavior. Urol Oncol 2004;22:410-4.

8 Boissier R, Ouzaid I, Nouhaud FX, et al. Long-Term oncological outcomes of cystic renal cell carcinoma according to the Bosniak classification. Int Urol Nephrol 2019:51:951-8.

9 Nouhaud F-X, Bernhard J-C, Bigot P, et al. Contemporary assessment of the correlation between Bosniak classification and histological characteristics of surgically removed atypical renal cysts (UroCCR-12 study). World J Urol 2018;36:1643-9.

10 Smith $A D$, Allen BC, Sanyal R, et al. Outcomes and complications related to the management of Bosniak cystic renal lesions. AJR Am J Roentgenol 2015;204:W550-6.

11 Winters BR, Gore JL, Holt SK, et al. Cystic renal cell carcinoma carries an excellent prognosis regardless of tumor size. Urol Oncol 2015;33:505.e9-505.e13.

12 Ploumidis A, Panoskaltsis T, Gavresea T, et al. Tumor seeding incidentally found two years after robotic-assisted radical nephrectomy for papillary renal cell carcinoma. A case report and review of the literature. Int I Surg Case Rep 2013;4:561-4.

13 Pandey M, Ramasamy M, Shukla M. Unusual progression of renal cell carcinoma with carcinomatosis peritoneii and Krukenberg tumour and alopecia with sunitinib therapy in young female. World J Surg Oncol 2018;16:1-5.

14 Jennison E, Wathuge GW, Gorard DA. Renal cell carcinoma presenting with malignant ascites. JRSM Open 2015;6:205427041558508.

15 Staderini F, Cianchi F, Badii B, et al. A unique presentation of a renal clear cell carcinoma with atypical metastases. Int J Surg Case Rep 2015;11:29-32.

16 Gonçalves MO, Benidir T, Erbano BO, et al. Peritoneal metastases from renal cell carcinoma: images in urology. Can Urol Assoc J 2014:8:391-2.

17 Esnakula AK, Naab TJ, Green W, et al. Extensive peritoneal carcinomatosis secondary to renal cell carcinoma with sarcomatoid and rhabdoid differentiation. BMJ Case Rep 2013;2013:bcr2013008725.

18 Boateng AA, Vinson MA, Mutema GK, et al. Malignant ascites and small renal mass: an unusual presentation of advanced renal cell carcinoma. Urology 2013;82:e28-9.

19 Tanaka K, Hara I, Takenaka A, et al. Incidence of local and port site recurrence of urologic cancer after laparoscopic surgery. Urology 2008;71:728-34.

20 Pradere B, Peyronnet B, Delporte G, et al. Intraoperative cyst rupture during partial nephrectomy for cystic renal Masses-Does it increase the risk of recurrence? J Urol 2018;200:1200-6.

21 Spaliviero M, Herts BR, Magi-Galluzzi C, et al. Laparoscopic partial nephrectomy for cystic masses. J Urol 2005;174:614-9.

Copyright 2021 BMJ Publishing Group. All rights reserved. For permission to reuse any of this content visit

https://www.bmj.com/company/products-services/rights-and-licensing/permissions/

BMJ Case Report Fellows may re-use this article for personal use and teaching without any further permission.

Become a Fellow of BMJ Case Reports today and you can:

- Submit as many cases as you like

- Enjoy fast sympathetic peer review and rapid publication of accepted articles

- Access all the published articles

- Re-use any of the published material for personal use and teaching without further permission

Customer Service

If you have any further queries about your subscription, please contact our customer services team on +44 (0) 2071111105 or via email at support@bmj.com.

Visit casereports.bmj.com for more articles like this and to become a Fellow 